\title{
"Cidadãos de bem" com armas: Representações sexuadas de violência armada, (in)segurança e legítima defesa no Brasil
}

"Good Citizens" with Weapons: Sexualized Representations of Armed Violence, (In)security and Legitimate Defense in Brazil

"Citoyens comme il faut » armés : représentations sexuées de violence armée, (in)sécurité et légitime défense au Brésil

\section{Rita Santos}

\section{OpenEdition}

\section{Journals}

Edição electrónica

URL: http://journals.openedition.org/rccs/4851

DOI: $10.4000 /$ rccs.4851

ISSN: 2182-7435

\section{Editora}

Centro de Estudos Sociais da Universidade de Coimbra

Edição impressa

Data de publição: 1 Março 2012

Paginação: 133-164

ISSN: 0254-1106

Refêrencia eletrónica

Rita Santos, " "Cidadãos de bem" com armas: Representações sexuadas de violência armada, (in)segurança e legítima defesa no Brasil », Revista Crítica de Ciências Sociais [Online], 96 | 2012 colocado online no dia 15 fevereiro 2013, criado a 19 abril 2019. URL : http://journals.openedition.org/ rccs/4851; DOI : 10.4000/rccs.4851 


\section{RITA SANTOS}

\section{"Cidadãos de bem" com armas: Representações sexuadas de violência armada, (in)segurança e legítima defesa no Brasil}

Este artigo procura examinar as estratégias discursivas utilizadas pelos movimentos a favor e contra o microdesarmamento no Brasil através da análise dos materiais de campanha das duas frentes no Referendo sobre a Proibição do Comércio de Armas de Fogo e Munições que teve lugar em outubro de 2005. A análise aponta para a utilização de representações e estratégias de mobilização do voto assentes em construções sexuadas das experiências e condutas de mulheres e de homens relativamente à probabilidade, lugares e protagonistas de vitimação armada, à conceção e ao exercício da legítima defesa enquanto direito do "cidadão de bem" e/ou privilégio. O estudo e a discussão destas representações são essenciais, uma vez que estas influenciam a forma como a violência e a (in)segurança é imaginada e percebida e, em especial a forma como, por sua vez, condicionam as políticas de combate e prevenção da violência.

Palavras-chave: Brasil; desarmamento; mulheres e violência; segurança; violência armada; vitimologia.

\section{Introdução}

A posse e utilização de armas de fogo, a violência perpetrada com este tipo de armas, bem como os debates sobre políticas de regulação destes instrumentos, geralmente referidos como políticas de microdesarmamento, ${ }^{1}$

\footnotetext{
${ }^{1}$ Por microdesarmamento, termo cunhado por Boutros-Boutros Ghali, em 1995, no Suplemento da Agenda para a Paz, entende-se "o desarmamento prático no contexto do uso de armas de pequeno porte e ligeiras, responsáveis pela morte de centenas de milhares de pessoas", em cenários de guerra e de paz. No plano nacional, inclui ações de monitorização, controlo, recolha, entrega e/ou destruição de armas de pequeno porte e armamento ligeiro, munições e explosivos nas mãos de combatentes e da população civil, bem como o desenvolvimento de programas de gestão responsável destes arsenais, nomeadamente através da criação e/ou reforma dos regimes legais que regulam a produção, comercialização, porte e posse de armas por parte de civis, e gestão/destruição de stocks (SEESAC, 2003). No plano internacional, destacam-se a criação de instrumentos regionais e internacionais que visam a regulamentação da produção e do comércio internacional, a fiscalização de transferências interestatais, a marcação e o rastreamento das armas e o desenvolvimento de diretrizes sobre armazenamento estatal (ibidem).
} 
têm sido amplamente analisados por várias disciplinas, sobretudo em contextos marcados por índices elevados de violência armada e de posse civil de armas. Os estudos de género, atentos ao "conjunto de discursos que atribui, altera e representa significados com base na pertença a uma categoria sexual" (Sjoberg e Gentry, 2007) e que estabelece hierarquias entre os traços tidos como masculinos e femininos, não são exceção.

A partir do final dos anos 90, sobretudo na América do Norte (EUA e Canadá), uma série de estudos tem-se debruçado sobre as repercussões sexuadas da utilização de armas de fogo e da violência armada, sobretudo em contextos de guerra e pós-guerra (Berdal, 1996; Small Arms Survey, 2005; Muggah, 2006). Salvo algumas exceções (Stange e Oyster, 2000; Farr et al., 2009; Stroud, 2012; Moura, Santos e Pureza, 2013), estas análises têm atentado nas formas como as relações de poder com base no sexo informam e moldam as atitudes de homens e mulheres ao longo do tempo face à posse e utilização destas armas fora desses contextos, negligenciando, contudo, as formas como são usadas e instrumentalizadas para afirmar, consensualizar ou questionar os entendimentos sobre vitimação, criminalidade e segurança que lhe subjazem e as políticas que se estruturam para lhes fazer face. Além disso, na sua maioria, este tipo de estudos têm-se centrado no universo das armas ilegais e das experiências criminais de homens e mulheres utilizadores de armas de fogo, em especial no seio de grupos armados não estatais como gangues e outros grupos criminais organizados (Connell, 1995; Stretesky e Pogrebin 2007; Kellner, 2008).

Por seu turno, as armas legais e, por consequência, os utilizadores e as utilizadoras legais de armas de fogo (geralmente referidos no contexto brasileiro como "cidadãos de bem"), um dos objetos deste artigo, têm merecido pouca atenção, sobretudo no que diz respeito às formas através das quais o género influencia as decisões de as portar e utilizar, as experiências da sua utilização, quer criminais quer não criminais, bem como as conceções de vitimação, insegurança e violência destes indivíduos.

Este artigo pretende analisar os discursos produzidos por e sobre mulheres e homens no que diz respeito à utilização criminal e não criminal de armas de fogo ao longo da campanha brasileira para o Referendo sobre a Proibição do Comércio de Armas de Fogo, o qual teve lugar a 23 de outubro de 2005. O Referendo, o primeiro do género a nível mundial, estava previsto no artigo 35 do Estatuto do Desarmamento ${ }^{2}$ e visava determinar se a proibição da comercialização de armas de fogo e munições em todo o

$\overline{{ }^{2} \text { Lei n. }}{ }^{\circ} 10.826$, o enquadramento legal que desde dezembro de 2003 passou a regulamentar a posse e utilização civil de armas de fogo no país. 
território nacional, inscrita no mesmo artigo, teria a aprovação popular e, consequentemente, entraria em vigor.

O presente artigo centrar-se-á nas representações das mulheres e homens avançadas pelas duas frentes de campanha (a favor e contra a proibição) e no carácter sexuado de conceitos-chave das propagandas, nomeadamente legítima defesa, "cidadão de bem" e violência armada. Procurarei, assim, dar resposta às seguintes questões: como é que os discursos das campanhas são moldados por ideologias de género? Quais são as suas implicações em termos de: a) perceção das características associadas às mulheres e homens, b) construção sexuada da vitimação armada (probabilidade e agentes), c) e conceções de legítima defesa e de segurança pública por estes veiculada.

A análise basear-se-á na programação das duas frentes no Horário Gratuito de Propaganda Eleitoral (HGPE) na TV, artigos de opinião ligados às duas frentes veiculados nos média e redes sociais e entrevistas realizadas com integrantes da campanha. ${ }^{3}$ A relevância desta análise prende-se com o reconhecimento de que as representações contra e a favor da proibição do comércio de armas de fogo de pequeno porte condicionam entendimentos sobre a situação da violência armada e (in)segurança pública bem como sobre políticas públicas e outras iniciativas pensadas para lhe dar resposta. Enquanto sistemas de produção, resistência e suspensão de significados, as representações envolvem e são resultado de relações de poder, não sendo nunca "meramente descritivas, mas sempre normativas e, por isso, excludentes" (Butler, 1994: 166). Como refere Laura Shepherd (2008: 21), "o discurso constitui a acção", na medida em que define os termos de inteligibilidade através dos quais uma realidade pode ser, simultaneamente, objeto de conhecimento e de ação. Neste caso específico, o que conta como violência armada, e em especial as vítimas e ameaças prováveis, bem como as soluções preconizadas para lhe dar resposta, são resultado de construções sociais moldadas e produto de dinâmicas de poder de ordem sexuada - mas também de cariz racial e de classe.

Este artigo argumenta que os retratos de mulheres e de homens, pese embora diversificados, e as representações sexuadas da violência armada e da (in)segurança pública presentes nos discursos das duas frentes em campanha, revelam que as normas de género tradicionais se mantêm presentes. De facto, o destaque atribuído às mulheres na campanha e a

\footnotetext{
${ }^{3}$ Este artigo foi elaborado no âmbito da bolsa de doutoramento financiada pela Fundação para a Ciência e Tecnologia (FCT, MCTES), Portugal (SFRH/BD/65469/2009) (2009-2013). O trabalho de campo de suporte a este artigo foi realizado entre agosto de 2010 e janeiro de 2011 e abril e outubro de 2011, no Rio de Janeiro, em São Paulo e em Brasília.
} 
presença de múltiplos retratos de mulheres nos discursos de cada frente parece indicar que a subordinação de género foi desconstruída na e pela campanha. Contudo, a grande visibilidade das mulheres apenas aparenta desconstruir a ordem de género, uma vez que os tipos ideais de feminilidade tradicionais são usados recorrentemente por ambas as campanhas para conferir legitimidade e autoridade às suas mensagens, excluindo-se representações femininas que não se coadunam com os estereótipos de género, como por exemplo utilizadoras regulares de armas.

Também os arquétipos de masculinidade presentes nas campanhas ecoam modelos hegemónicos de masculinidade nas suas versões "benignas" - os "cidadãos de bem", armados, cujo objetivo é garantir a proteção dos seus bens e família, no lado do Não; e os homens a favor da proibição, na sua maioria especialistas e/ou profissionais de segurança pública, que se mobilizam por razões racionais, ideológicas e não pessoais. Estes são tidos como necessários para se contraporem a masculinidades hegemónicas "malignas", hipersexualizadas, atribuídas aos "bandidos", ao crime organizado e ao narcotráfico pela frente do Não. Além disso, as duas frentes veiculam entendimentos sexuados de legítima defesa, criminalidade e violência armada, que põem em destaque de forma desigual experiências de (alguns) homens e mulheres enquanto vítimas e agentes de violência. As duas frentes, em maior ou menor grau, reproduzem assim relações de poder de género assimétricas, privilegiando a ótica masculina na construção social da violência armada e da legítima defesa.

\section{Universos paralelos: guerra e violência armada como produtos e repro- dutores de relações de género}

O estudo da guerra e do militarismo tem ocupado um lugar central nas análises feministas nos mais diversos campos das Ciências Sociais. As análises feministas das Relações Internacionais, em particular, têm-se dedicado a estudar o processo de atribuição de papéis sociais diferenciados em função do sexo e a subalternização das experiências das mulheres em contextos de guerra, pós-guerra e outras práticas violentas nas relações internacionais (Enloe, 1983, 2000; Tickner, 1992; Pettman, 1996). Vieram, assim, chamar a atenção para o peso que estes papéis sociais têm na consolidação e perpetuação de uma cultura de violência ou "sistema de guerra" (Reardon, 1985).

Esta estrutura de poder patriarcal é entendida como "a parte central da estrutura conceptual que determina virtualmente toda a ação humana, tanto pública, como privada" (ibidem: 15), através da imposição de papéis sexualmente definidos e hierarquizados entre si. Traduz-se numa ordem social competitiva, baseada em princípios autoritários, que pressupõe um 
valor desigual entre seres humanos, e que é colocada em prática através de força coerciva, cimentando e naturalizando relações de poder válidas em contextos de guerra e em contextos de paz (ibidem: 10).

\subsection{Mitos e construções sexuadas da guerra e das armas de fogo: "guerreiros justos" e "cidadãos de bem" e "almas belas"}

A construção e perpetuação deste sistema de guerra recorre a mitos e a estereótipos de género que, ao serem essencializados, naturalizam e legitimam a existência de relações de poder desiguais. Estas representações de género tornam possíveis atos de violência interpessoal, bem como atos de violência organizada, e, por sua vez, a violência e a guerra reconstituem e reforçam estes mitos, contribuindo para legitimar a guerra em si.

A narrativa dos "guerreiros justos" e das "almas belas", identificada por Elshtain (1987) como estando na base da explicação e justificação das guerras, é um dos exemplos deste tipo de estereótipos. O protagonista desta narrativa é o "guerreiro justo", um herói que se sacrifica violentamente para proteger (as suas) mulheres e crianças do inimigo ("guerreiro injusto"). Assim, os "guerreiros justos" não vão para a guerra para matar, mas sim para morrer por uma causa (Elshtain, 1991). Segundo esta narrativa, as mulheres, ou as "almas belas", constituem simultaneamente os objetos e os prémios de guerra e os motivos justos do conflito. São "almas belas" pois são inocentes, vulneráveis, dependentes da proteção de outros (homens) e (erradamente) pacifistas, dado que desconhecem a verdadeira natureza da guerra (Elshtain, 1987). Esta narrativa enfatiza ainda o papel das mulheres enquanto mães, associando a sua identidade com a responsabilidade pelo cuidado da família e das crianças em casa (esfera doméstica e pátria) e com o apoio moral e logístico da guerra, dado que simbolizam a pureza pela qual importa lutar e resgatar. A guerra é, assim, um meio necessário para garantir a proteção dos mais fracos e das vítimas da violência, cuja responsabilidade recai no (mito do) cidadão guerreiro (ibidem).

Esta narrativa da guerra é uma das explicações para a associação frequente e quase exclusiva dos homens à violência e aos processos de paz formal, sobretudo na qualidade de líderes e especialistas, e das mulheres à paz e à vitimação. No primeiro caso, traduz o entendimento privilegiado de que o sistema patriarcal tem do papel que o homem deve desempenhar na condução e na realização da guerra em nome dos desprotegidos (e sobretudo das desprotegidas) e no delineamento de fins negociados para os conflitos, onde se reestruturam as relações de poder e se definem novas prioridades. A associação 'mulheres-paz' constrói-se por via da perceção de que as mulheres são inerentemente pacíficas e pacifistas, em detrimento da sua 
capacidade de mobilização efetiva. Esta idealização, apesar de aparentar corresponder a uma valorização da feminilidade, na prática contribui para a definição da mulher enquanto dependente eterna ('mulher-vítima').

O entendimento destes mitos enquanto construções sociais permite desafiar a associação essencialista entre guerra e agressividade inata dos homens e entre paz e mulheres. De facto, as críticas feministas à associação entre masculinidade e guerra e uso da força têm-se centrado em particular na análise da construção e legitimação de um tipo de masculinidade (hegemónica) (Connell, 1995) e na enorme influência que este tem na configuração de uma cultura da violência. Este tipo ideal de masculinidade é uma construção cultural hegemónica que, apesar de não equivaler às atitudes da maioria dos homens, sustém e legitima o sistema patriarcal na vida social e política. Trata-se de uma versão particular e idealizada de masculinidade, cujos ingredientes principais, na atual cultura ocidental, são a coragem, a agressividade, a heterossexualidade, a homofobia, a racionalidade e a subordinação das mulheres. Para além disso, é em relação a esta que imagens de feminilidade e outras masculinidades, tidas como inferiores (homossexualidade, transexualidade), são marginalizadas e subordinadas.

Segundo Connell (1995: 212), a defesa da posse de armas de fogo equivale "simbólica e materialmente à defesa da masculinidade hegemónica", uma vez que as armas representam a capacidade de controlar o outro e esta capacidade atribui poder ao seu utilizador. Mesmo quando as armas são pensadas apenas enquanto formas de legítima defesa, a masculinidade hegemónica permanece implicada no seu uso. Nestes casos, uma vez que elas servem para suprir o medo de dominação por outrem, correspondem ao que Kimmel (1996: 6) defendeu sobre a masculinidade dominante: "a masculinidade tem menos a ver com a busca pela dominação, do que com o medo de sermos dominados por outros, e de vermos os outros com poder e controlo sobre nós." Como a feminilidade é construída, em sociedades patriarcais, em oposição à masculinidade, as implicações desta noção de masculinidade para a vitimação e para as feminilidades são profundas, dependendo de e reforçando-se a partir de construções patriarcais que associam as mulheres à dependência e os homens à autossuficiência.

As ligações entre poder, controlo, masculinidade e violência armada são exploradas no trabalho de James Gibson sobre as culturas paramilitares nos EUA (1994). Segundo esta análise, a derrota dos EUA pelo Vietname, sendo os EUA claramente superiores em termos de efetivo militar e sofisticação tecnológica, representou um duro golpe na representação coletiva simbólica da força e poderio do país, levando à emergência de um novo ethos de guerra. Essa filosofia resume-se à luta entre o bem e o mal, estando 
a capacidade de dominação do inimigo através da violência associada a uma "masculinidade virtuosa". Todo e qualquer tipo de dependência é identificado com fragilidade e vitimação, sendo construído como feminino.

A masculinidade virtuosa é, assim, construída através da distinção entre "os bons rapazes" (ou os "cidadãos de bem") e os "maus rapazes" (Gibson, 1994). Para ambas as identidades a dominação é uma característica central, sendo o carácter da dominação (controlada ou descontrolada) e o alvo da violência determinantes para apurar o cariz benigno ou maligno da masculinidade. Estes dois tipos de masculinidade correspondem a idealizações-espelho do que Elshtain (1987) denominou de "guerreiros justos", por oposição aos "guerreiros injustos". De facto, se é verdade que os utilizadores ilegais de armas de fogo, nomeadamente em contextos de grupos armados como gangues, se sentem "empoderados" ao desempenhar uma performance de dominação, não é menos verdade que esta reforça, por outro lado, a sua marginalização. Já a versão virtuosa (legal) da utilização de armas está acessível a indivíduos já privilegiados, uma vez que implica o pagamento do processo de licenciamento, e lhes permite o acesso a modelos de masculinidade bem vistos e promovidos culturalmente. Nesta construção, as mulheres são representadas como "vítimas naturais" e como os meios através dos quais a masculinidade patriarcal é legitimada e reforçada (Connell e Messerschmidt, 2005).

Segundo este tipo idealizado de masculinidade virtuosa, a capacidade de responder à violência está sempre presente, mas tem de ser utilizada de forma regrada. A análise de Kevin O’Neil (2007: 459) sobre as representações de masculinidade e violência veiculadas pela National Rifle Association (NRA) através da publicação Armed Citizen, que compila artigos baseados em experiências reais de legítima defesa, evidencia a presença "de um tipo ativo e especialmente vigilante de cidadão, claramente masculino". Para o autor a popularidade destas representações deriva da presença de discursos sobre a masculinidade que enfatizam o papel das armas enquanto meio de reação virtuoso e realista face às ameaças e perigos do mundo atual.

Como referi atrás, as construções tradicionais de feminilidade identificam as mulheres com a passividade, vulnerabilidade e dependência, caracterizações essas que contribuem para a normalização da violência contra as mulheres. Estas construções são tão resistentes que, ao contrário do que seria de esperar, alguns cursos de autodefesa dirigidos a mulheres reproduzem estes entendimentos e encorajam respostas passivas perante uma situação de ameaça física (Hollander, 2004). Na verdade, os discursos de autodefesa não são necessariamente pós-patriarcais, uma vez que "as definições patriarcais de feminilidade, que a associam à dependência e ao medo, produzem 
um desarmamento cultural das mulheres que pode ser tão eficaz quanto o desarmamento físico" (Connell, 1995: 83).

A lógica do raciocínio da autodefesa armada é a de que, se houvesse mais mulheres treinadas e familiarizadas com o uso e recurso a armas de fogo, aumentar-se-iam as hipóteses de afirmação do seu poder e a sua capacidade de resistência a tentativas de dominação (Hollander, 2004). Neste sentido, este tipo de atuação pode ser considerado como um meio de "desconstruir as relações de género" (Deutsch, 2007), constituindo uma passagem da imagem das mulheres como vítimas à prática de mulheres capacitadas. Pese embora o facto de as armas de fogo constituírem, em alguns casos, uma forma de apoio às mulheres (Stroud, 2012), sem uma alteração significativa dos discursos sexuados de violência e vitimação a sua utilização pode transformar-se num (novo) foco de violência contra essas mesmas mulheres, sobretudo se tivermos em consideração o padrão de vitimação provável (violência cometida por conhecidos). A associação entre patriarcado, vitimação e capacidade de recorrer à violência para defesa da propriedade e da família tem sido pois perversa para as mulheres, o que, juntamente com a identificação das mulheres como vítimas naturais, tem possibilitado e legitimado atos de violência contra as mulheres perpetrados por homens.

De facto, afirmar que a utilização de armas corresponde a um padrão de masculinidade porque os homens utilizam armas ou porque a maioria dos utilizadores de armas são do sexo masculino não é um argumento válido. Porém, masculinidades e feminilidades são reconstruídas através dos discursos sobre utilização de armas, violência e legítima defesa, nomeadamente na forma como os homens se posicionam como protetores da família, e em especial das suas mulheres e crianças (Stroud, 2012; Moura, Santos e Pureza 2013), na forma como os casais decidem e negoceiam a utilização de armas de defesa (Stroud, 2012) e na forma como as armas repõem a masculinidade de homens mais velhos (Stroud, 2012; Moura, Santos e Pureza, 2013).

No primeiro caso, sublinha-se o uso de armas como uma reação responsável e racional, por oposição a uma reação ingénua e emocional, a um mundo perigoso. Nesta construção dos homens enquanto protetores e das mulheres como protegidas, os traços valorizados (racionalidade, força) estão associados à masculinidade e as características depreciadas associadas à feminilidade (vitimação e dependência). Relacionado com esta construção, está o papel de protetor da família, atribuído ao homem armado. Este elemento é particularmente interessante uma vez que não existe nada à partida, segundo a hierarquia de características atribuídas a homens e a mulheres, que justifique a delegação do uso de armas de fogo aos homens. Na verdade, apesar de muitos dos discursos de e sobre utilizadores de armas as classificarem 
de "equalizadores" em caso de agressão violenta, vários mantêm que cabe ao homem defender a família na esfera privada. Este aspeto é corroborado por análises sobre agregados familiares heterossexuais onde ambos os cônjuges estão aptos e familiarizados a utilizar armas de fogo, e onde, em vários casos, quando a família está toda presente o papel de defesa (quer autodefesa, quer de outrem) é atribuído ao homem, por contraposição às situações onde um dos cônjuges não está presente (Stroud, 2012). Segundo este modelo de masculinidade hegemónica virtuosa, alguns homens procuram e utilizam armas de fogo enquanto forma de cumprirem o seu papel (percecionado e construído) de protetores. As consequências deste entendimento são o sobredimensionamento da vulnerabilidade das mulheres e a sua fixação enquanto seres que precisam de proteção por parte dos homens nas suas vidas (Hollander, 2004).

Por fim, a utilização de armas de fogo surge como forma de repor a masculinidade hegemónica, manifesta em casos onde o indivíduo equaciona a perda de capacidades físicas decorrente do envelhecimento como perda de capacidade de resistência e resposta a tentativas de dominação por parte de outros e, logo, como aumento da probabilidade de vitimação. Dada a centralidade da capacidade física para exercer violência na construção das masculinidades e o medo dos homens face à possibilidade de outros homens "nos desmascararem, emascularem, e revelarem a nós próprios e ao mundo que não estamos à altura, que não somos verdadeiros homens" (Kimmel, 2010: 120), fica claro o papel das armas de fogo enquanto símbolos de assunção de virilidade e instrumentos de recuperação da "masculinidade diminuída".

\subsection{Visões e revisões feministas da guerra e do feminismo armado}

Apesar de partirem da premissa comum de que as relações de poder moldadas pelo sexo/género por sua vez moldam e são moldadas pelos entendimentos e práticas de guerra e de paz, as perspetivas feministas no campo da segurança e da paz pautam-se pela diversidade, ecoando as orientações das tendências gerais do feminismo. De facto, se é verdade que os vários feminismos reconhecem a natureza sexuada dos conflitos armados, dos regimes militares e dos diferentes tipos de violência, nem todas as correntes têm denunciado o militarismo enquanto forma de dominação patriarcal, nem adotado posições antiguerra ou pacifistas. Uma das interpretações desta resistência prende-se com distinções internas no seio dos feminismos a respeito da natureza das diferenças de género (debate entre feministas da igualdade e feministas da diferença) e divergências relativamente às estratégias adequadas para eliminar a subordinação das mulheres e dos homens. Aqui destaca-se o debate acerca da importância, eficácia e/ou 
cariz contraproducente da apropriação de imagens e símbolos associados à maternidade (Ehlstain, 1987 Dietz, 1985).

$\mathrm{O}$ feminismo liberal tem defendido a igualdade de acesso de homens e mulheres às estruturas de poder e a instrumentos da violência, nomeadamente ao setor militar. Recusa, inclusivamente, a visão essencialista das mulheres enquanto sexo pacífico, que considera contribuir para o reforço da estrutura opressora das mulheres e dos homens cuja performance não se enquadra na masculinidade hegemónica. Acredita que a participação feminina nas estruturas de poder lhes permite o acesso a uma cidadania de "primeira classe", dotando-as de oportunidades de transformação da realidade, desde logo a paz (Burgieres, 1990: 5).

Já o feminismo da diferença sublinha a existência de diferenças biológicas (posição minoritária dentro desta corrente), valorativas e comportamentais entre mulheres e homens, pelo que a emancipação das mulheres não se alcança com garantias de igualdade de oportunidades, mas sim através da mudança das relações sociais a um nível micro. Esta corrente tem advogado a valorização das experiências e recursos de mulheres na construção da paz, ligando-as quer à especificidade biológica (maternidade), quer à socialização (cuidado). Gilligan (1982), por exemplo, defende que as mulheres reagem moralmente a uma "voz diferente", mais concreta e contextual, focando-se nas relações e na responsabilidade, em detrimento dos princípios e direitos abstratos. Na mesma linha, Ruddick (1982) desenvolveu a noção de pensamento materno, que não é exclusivo das mulheres e das mães, explorando as práticas maternalistas que encorajam capacidades e valores pacifistas. Para a autora, não existe contradição entre a defesa do direito das mulheres à participação nas forças armadas e a apologia de uma filosofia pacifista, uma vez que a sua inclusão pode contribuir para "pacificar" estas instituições, argumento também utilizado pelo feminismo liberal. Alguns segmentos desta tradição, assim como da liberal (Peach, 2004), tendem a apoiar versões de guerra próximas à da Guerra Justa, o que tem suscitado debates intensos entre as várias tradições e no seio de cada uma delas, nomeadamente a ideia de que, em virtude desta posição, se aceita a guerra como um instrumento político legítimo e justificado (Elshtain, 1987 Cohn e Ruddick, 2004).

Por fim, o feminismo pós-estruturalista e crítico rejeita o universalismo das experiências das mulheres (e dos homens), sublinhando a não correspondência com a realidade e o cariz contraproducente destas categorizações, uma vez que existem outros elementos formadores da identidade, como etnia, nacionalidade, religião e classe. Este feminismo acusa assim a constituição, dentro das propostas feministas, de um padrão hegemónico 
de feminilidade, que enfatiza os discursos e experiências da "mulher branca, ocidental e heterossexual” (Westwood e Radcliffe, 1993: 5). Recusa os estereótipos mulher-passiva-pacífica e homem-violento, e chama a atenção para o papel dos mesmos na perpetuação de uma sociedade sexista e militarizada. Faz um apelo à necessidade de conhecer as diversas realidades vividas pelo sexo feminino em situações de conflito, violência e construção da paz, sublinhando o carácter desproporcionadamente masculino (porque correspondente ao filão da masculinidade hegemónica) dos processos de militarização, segurança e cidadania (Pettman, 1996: 107). A paz é vista como dependente da rutura com os estereótipos e a promoção de novas relações de poder entre homens e mulheres, nomeadamente um tipo de cidadania menos dependente de valores militares (Stiehm, 2001; Enloe, 2000). Mary Dietz (1985) argumenta que é a consciência política feminista, e não a feminina, que tende a levar homens e mulheres feministas a adotar posições pacifistas.

Este debate sobre as relações entre feminismo, paz e não violência está igualmente patente nas discussões sobre utilização civil de armas de fogo. Uma grande parte dos feminismos tem contrariado a ideia de que estas podem constituir um instrumento de emancipação das mulheres. Uma das vozes mais críticas desta associação foi a feminista norte-americana Betty Friedan, que, em 1993, descreveu a tendência para as mulheres adquirirem armas de fogo como uma "perversão horrífica e obscena do feminismo" e denunciou o uso do NRA do slogan "Refuse to be a victim" (originário do movimento antiviolência sexual, designadamente o "Taking back the night", que promove a autodefesa como forma de resposta) como "utilização falsa do feminismo" (apud Browder, 2006: 231).

Apesar disso, existe um corpo já significativo de literatura feminista que analisa as implicações positivas para as mulheres da posse e do uso de armas, defende o conhecimento e visibilização das "mulheres de armas" e advoga uma conceção de "feminismo armado" (Wolf, 1993; Stange e Oyster, 2000). De acordo com estas perspetivas, as mulheres devem aprender a agir individualmente e a garantir a sua segurança, sendo a arma de fogo um instrumento particularmente eficaz para a sua autodefesa, ao esbater as supostas diferenças físicas entre mulheres e homens. O "Power Feminism", cunhado por Naomi Wolf (1993), celebra a posse e a utilização de armas por parte das mulheres como expressão de rejeição do estatuto de vitimização.

Outro dos elementos discursivos comuns a estas formas de feminismo armado corresponde à adaptação do discurso próescolha, usado pelos movimentos a favor da legalização do aborto, e que questiona: "se não confiamos ao governo o nosso corpo, os nossos órgãos e apetites, porquê confiar-lhe as nossas vidas e segurança?” (Stange e Oyster, 2000: 56). 
Se, por um lado, estas formas de feminismo armado têm alguns pontos de contacto com o feminismo dos movimentos antiviolência sexual - defendendo, por exemplo, os cursos de autodefesa como instrumentos de capacitação das mulheres - por outro lado, divergem num aspeto essencial: o porte e a utilização da arma, já que esta pode ser usada em várias circunstâncias e por qualquer pessoa (Flood, 1999). Esta é uma das críticas feministas à corrente do feminismo armado, questionando a eficácia das armas de fogo na autodefesa das mulheres em situações de violência familiar ou entre conhecidos, uma das formas de vitimação mais provável das mulheres (Jones, 1994). Dados sobre os EUA, Europa e América Latina sugerem que a posse de arma em casa aumenta a probabilidade de morte de mulheres e outros membros da família, nomeadamente em casos de disputa familiar (Miller, Azrael, e Hemenway, 2000).

Um dos elementos mais controversos neste domínio prende-se com os pressupostos e implicações do feminismo armado. Ao aceitar a noção marcial de cidadania e concetualizar o poder como derivado, em última análise, da capacidade de exercer dano e violência, o feminismo armado corresponde a um "atalho feminista" (Browder, 2006) - "salta" por cima de questões centrais para a igualdade de género, como a igualdade de oportunidades, de emprego, de salário igual para trabalho igual, etc. e equaciona a igualdade com a capacidade de exercer violência.

\section{O Referendo da Proibição do Comércio de Armas no Brasil: atores e disputas de significados sobre violência armada e segurança pública}

Em outubro de 2005 o Referendo sobre a Proibição do Comércio de Armas no Brasil levou quase 96 milhões de brasileiros às urnas para responder à pergunta: "O comércio de armas de fogo e munição deve ser proibido no Brasil?”. A consulta popular contou com uma participação maciça da população e resultou na vitória do Não, com $63,94 \%$ dos votos, enquanto o Sim obteve 36,06\% (Fuks e Paiva, 2006: 204).

Com cerca de 14,8 a 17,6 milhões de armas em mãos civis, o Brasil ocupa o oitavo lugar em 178 países, no que diz respeito ao arsenal civil (GunPolicy.org, 2011). Entre 1979 e 2003, antes da realização do Referendo, tinham-se registado mais de 500000 mortes perpetradas com armas de fogo em contextos diversos - situações de confronto entre grupos criminosos (nomeadamente fações de droga e milícias) e a polícia, violência interpessoal e conflitos familiares - o que correspondia a quatro vezes mais óbitos do que os apurados durante os 50 anos do conflito israelo-palestiniano (Geneva Declaration, 2011). Apesar da diversidade de incidentes violentos, a maioria das vítimas diretas eram (e são) invariavelmente 
as mesmas: homens jovens, pobres e negros (Instituto Sangari e Ministério da Justiça, 2011: 26).

Face a esta realidade da violência armada do país, indivíduos e movimentos sociais procuraram mobilizar e debater publicamente formas de minimização e prevenção deste tipo de violência, discutindo a utilidade (ou não) da introdução de formas de controlo de armas de fogo, entre as quais um novo regime jurídico e a proibição de posse civil de armas. Nos anos anteriores ao Referendo, vários movimentos da sociedade civil organizada, nomeadamente as ONG Viva Rio (Rio de Janeiro) e Sou da Paz (São Paulo), a Rede Desarma Brasil (envolvidas na Frente do Sim) e o Movimento Viva Brasil (São Paulo) (envolvido na Frente do Não) acompanharam o processo de redação, a aprovação e a implementação de um novo enquadramento jurídico de controlo de armas de fogo e munições, iniciado em 1999, bem como a Campanha nacional de Entrega Voluntária de Armas, prevista no Estatuto do Desarmamento, que decorreu entre junho de 2004 e outubro de 2005, e resultou na entrega e destruição de cerca de 443719 armas de fogo (Fuks e Paiva, 2006: 205).

O processo do Referendo contou com a participação destes movimentos, mas ganhou, no Congresso brasileiro, representantes oficiais: a Frente Parlamentar por um Brasil sem Armas, presidida pelo senador Renan Calheiros (Partido do Movimento Democrático Brasileiro - PMDB-AL), e a Frente Parlamentar pelo Direito da Legítima Defesa, presidida pelo deputado Alberto Fraga (Partido da Frente Liberal - PFL-DF). Às frentes coube promover o debate entre as duas posições, nomeadamente nos meios de comunicação, incluindo o direito ao Horário Gratuito de Propaganda Eleitoral HGPE na rádio e na TV. ${ }^{4}$

É importante sublinhar que os discursos aqui analisados são produzidos pelos atores diretamente interessados no resultado da votação, que se declararam abertamente defensores de uma determinada posição, o que tem implicações para as próprias características dos discursos e do debate. Por um lado, os interlocutores não pretendem deixar-se convencer mutuamente. Por outro lado, verifica-se o esforço por elaborar e veicular argumentos potencialmente aceitáveis pelo adversário, tendo em vista convencer o público em geral e os cidadãos inclinados a votar na frente adversária. Como lembra Christina da Cunha (2006: 58), "neste referendo a propaganda gratuita na televisão assumiu uma importância ímpar, pois não se tratava de uma eleição ordinária,

${ }^{4} \mathrm{O}$ tempo de antena diário para cada frente era de nove minutos a que se somavam vinte clips de trinta segundos ao longo da programação, durante um período de vinte dias (de 1 a 20 de outubro de 2005). 
de uma disputa entre candidatos e partidos, mas de uma ideia a respeito de um tema que a população brasileira não se debruçou antes para pensar".

$\mathrm{Na}$ campanha disputaram-se perspetivas diferentes sobre princípios (direito à vida versus direito individual à legítima defesa); diagnósticos da violência armada e insegurança no país (arma de fogo como vetor de violência sobretudo ao nível interpessoal versus omissão do Estado, causas sociais e armas ilegais nas mãos de "bandidos"); prognósticos (maior controlo sobre circulação das armas, dificultando o acesso às armas por parte dos bandidos e redução dos "crimes de proximidade" versus aumento da violência, do comércio ilegal de armas e da procura da segurança privada, com efeitos sobretudo nos pobres); e finalmente a credibilidade dos programas, com acusações de distorção de informações de ambas as partes.

Durante o período de campanha, a Frente por um Brasil sem Armas recorreu aos símbolos que marcaram a campanha do desarmamento, exibindo cenas referentes à destruição de armas, à aprovação do Estatuto do Desarmamento e imagens de mães, defensoras da vida, e também aos argumentos e slogans já amplamente difundidos, como por exemplo "pela vida", "menos armas, menos mortes”. Já a campanha da Frente pelo Direito da Legítima Defesa sublinhou medos que habitam o imaginário social e cultural brasileiro, como a ameaça da retirada de direitos e a descrença no governo e nas instituições, colocando-se do lado do povo e elegendo "os políticos" como adversário:

No nosso programa não temos artistas famosos que vivem em condomínios cercados de toda a segurança. Nossos artistas são o povo brasileiro: o agricultor, o policial aposentado, gente como você que precisa se proteger... . (2. Programa do Não, 02.10.2005; ênfase da autora)

A estratégia foi facilitada pela posição favorável do presidente Lula e de vários membros do seu partido à proibição do comércio de armas. Assim, a campanha do Sim ganhou ares de oficial e o Não pôde apresentar um discurso de oposição a um governo caracterizado como ineficiente na área da segurança pública, um governo que "não lhe dá seus direitos básicos" (13. ${ }^{\circ}$ Programa do Não,13.10.2005).

\section{Protagonistas e apelos das campanhas: as mulheres e os homens do Sim e do Não}

A campanha do Sim, num primeiro momento, deu grande destaque a depoimentos de celebridades e a um discurso mais emotivo, enquanto a do Não destacou a figura da jornalista ("pivô") do seu programa, que seguia 
o formato de "Noticiário", e as vozes das "pessoas comuns", configurando um discurso de teor mais pragmático e ideológico. Num segundo momento, a campanha do Sim passou a adotar um apelo menos emocional e mais pragmático, dando espaço a pessoas comuns e a especialistas, usados alternadamente com depoimentos pessoais que relatavam situações de violência.

Uma das representações mais comuns das mulheres na campanha do Não foi a "mulher honesta", "cidadã de bem", que se sente desprotegida perante os "bandidos", que detêm armas ilegais, quer porque foi vítima de violência direta ou indireta, quer porque receia vir a sê-lo:

Mara Assaf: (Introdução da pivot: Perdeu um filho nas mãos de bandidos mas ganhou coragem para dizer bem alto que não vai abdicar dos seus direitos de cidadã) Estou tentando dar voz ao filho que me foi tirado. Se atrás da arma que tiron o meu filho tinha um assassino ele é produto do desgoverno. Que tipo de vida eles estão defendendo? Uma vida em que a população vive ameaçada, atrás das grades? (4. Programa do Não, 04.10.2005)

Teófila Alboz, Dona de Casa: Nós estamos a ser assaltados 6, 7 vezes por dia. Eu ando na rua que nem mendiga, porque é tanto assalto. Já fui assaltada vinte vezes. E isto não pode continuar. ( $7 .^{\circ}$ Programa do Não, 07.10.2005)

Marina Glória de Paiva, Paulistana: Eu moro sozinha, tenho um sítio aqui perto de São Paulo e eu faço uso da arma pelo menos para me defender. (14. ${ }^{\circ}$ Programa do Não, 14.10.2005)

Meire de Lima, Pernambucana: antes eu pensava em votar "Sim", mas depois eu pensei e achei melhor votar "Não" porque a gente honesta vai ficar desarmada e os bandidos vão continuar armados. É um risco muito grande. (14. ${ }^{\circ}$ e $15{ }^{\circ}$ Programa do Não, 14 e 15.10.2005)

Fumiyo Kurisaki, Presidente do Movimento das Vítimas da Violência pela Justiça e Paz: (Introdução da pivot: É comum dizerem que nós, mulheres, não temos tanto envolvimento com o tema deste referendo. A história desta mulher prova o contrário.) Antes eu pensava em votar "Sim" porque eu realmente acreditava de que aconteceria de que howvesse desarmamento pro lado dos bandidos, mas eu vou votar "Não" porque eu vejo que os bandidos vão se armar ainda mais do que boje e que realmente eles não compram armas legais. (13. ${ }^{\circ}$ Programa do Não, 13.10.2005)

A identificação com a representação "mulher honesta" surge nos relatos de forma explícita através da identificação do "Nós estamos a ser assaltados", 
"A gente honesta vai ficar desarmada e os bandidos vão continuar armados", "A população vive ameaçada". Três dos relatos são enunciados por mulheres que viveram pessoalmente situações de violência (assalto e perda de filho) e dois expressam o receio da vitimação. Através destes relatos, a frente do Não posiciona-se e posiciona os seus sujeitos do lado do "cidadão de bem", deixando do outro lado o "bandido", os "criminosos", salientando que "realmente eles não compram armas legais". A representação da "mulher honesta" é construída sobre o estereótipo das mulheres enquanto figuras de respeito, responsáveis pelo cuidado da família e da casa. Ao sentirem-se desprotegidas perante os "bandidos", que detêm armas ilegais, quer porque foram vítimas, ou porque receiam vir a sê-lo, mostram-se, em última análise, dispostas a utilizar armas de fogo para zelar pelo que lhes pertence. A única mulher neste conjunto de relatos, e na campanha do Não, que usa individualmente armas de fogo para autodefesa, é retratada igualmente como honesta e sozinha (logo, indefesa). Através da sua fala, reforça-se a divisão dos sujeitos entre honestos e desonestos e a sua correspondência com fins honestos ("pelo menos para me defender") e desonestos das armas de fogo.

Convém sublinhar que o slogan da campanha, introduzido no início de todos os programas do Não pela pivô e repetido por vários homens e mulheres ao longo da campanha, era "Eu nunca pensei em ter uma arma, mas também não quero tirar o direito de quem precisa ter", o que denota a importância do argumento dos princípios (direito à legítima defesa) na campanha do Não. ${ }^{5}$ Apesar desta orientação geral, a campanha apresentou relatos de uso efetivo de armas para legítima defesa na quase totalidade enunciados por homens, oriundos sobretudo da classe média (o fazendeiro Wilson da Silva, os comerciantes Nadir Alvarenga, João Fernandes de Oliveira, Lázaro Santana, e o policial aposentado, nos $4 .^{\circ}, 7 .^{\circ}$ e $9 .^{\circ}$ Programas do Não). Este aspeto é problemático uma vez que, apesar de os dados sobre armas registadas no Brasil apontarem para uma grande maioria de utilizadores masculinos, várias mulheres são de facto detentoras e utilizadoras de armas de fogo, nomeadamente em termos desportivos e venatórios (Dreyfus e Nascimento, 2005: 140). Neste sentido, a ausência de relatos femininos de utilizadoras regulares de armas, nomeadamente caçadoras, desportistas e apologistas da legítima defesa armada é significativa e denuncia a exclusão, do leque de identidades femininas representadas, daquelas que rompem com os estereótipos de género.

Abaixo transcrevem-se alguns relatos de homens proprietários de armas que explicam a necessidade das armas para proteger a família, o negócio e propriedade (legítima defesa):

\footnotetext{
${ }^{5}$ Este aspeto será desenvolvido em maior pormenor à frente.
} 
Jornalista: O senhor depende da arma para defender a sua família, o seu património?

Policial aposentado: Eu dependo da arma para defender a minha família e todos os policiais militares também necessitam. Tem que estar sempre com o olho aberto, com as portas fechadas e com segurança em casa, porque nunca se sabe quem vai chegar. E fica muito triste, por causa das leis, a gente não poder reagir, porque se não morre. Eu vou votar não.

Nadir Alvarenga, Paraíbuna, comerciante: Sou um cidadão de bem e por isso tenho direito a ter a minha arma. Preciso dela para segurança, por causa do negócio, pela família. E eu só entrego a minha arma, quando os bandidos entregarem as deles.

(4. ${ }^{\circ}$ Programa do Não, 04.10.2005)

Estas representações ecoam modelos hegemónicos de masculinidade nas suas versões 'benignas', dizendo respeito a “cidadãos de bem”, armados legalmente, cujo objetivo é garantir a proteção dos seus bens e família, perante a ameaça real dos "bandidos", do crime organizado, ${ }^{6}$ que são retratados de forma hipersexualizada, isto é, mostrando traços extremos de masculinidade hegemónica:

Voz off: Segundo dados do IBGE, existem 5 milhões de crianças que têm o seu futuro ameaçado. Outra pesquisa, do DIIESE, mostra que quase metade dos desempregados das áreas metropolitanas do Brasil são jovens, ou seja, têm entre 16 e 24 anos.

Pivô: Daí para a criminalidade é um pulo. O jornal Folha de S. Paulo trouxe nesta segunda-feira uma notícia preocupante.

Voz off: o jovem corresponde a 50\% dos presos com arma no Brasil. São armas ilegais. A pesquisa foi feita na Grande São Paulo, Santos e Campinas pela Secretaria de Segurança Pública de São Paulo. Começou em Janeiro de 2004, logo depois da entrada em vigor do Estatuto do Desarmamento [...]. Segundo a pesquisa o portador de arma é jovem, morador de periferia e de baixa renda.

\footnotetext{
${ }^{6}$ No artigo de opinião "A solução radical", de Carlos Heitor Cony, publicado na Folha de S. Paulo, de 26 de outubro de 2005, reitera-se ironicamente esta associação entre armas e masculinidade e ridiculariza-se a realização do Referendo: "O homem, qualquer homem, já vem armado pela natureza: o falo. Em nome dele, ou melhor, na posse dele, todas as atrocidades são cometidas, não apenas contra a mulher, vítima mais disponível para qualquer tipo de violência, mas contra a humanidade em geral, uma vez que os homens, confiados em seu poderoso armamento, brigam entre si para conquistar a hegemonia do poder e da força. Daí que julgo necessário um novo e urgente referendo sobre o porte e o uso do falo."
} 
Pivô: O Programa do Fantástico mostrou recentemente o efeito da mistura entre juventude, o mundo do tráfico e as armas. São jovens consumindo drogas e carregando armas ilegais [imagens de favelas, rapazes fortemente armados e assaltos de carro]. Eles ficam em pontos estratégicos do morro para alertar os traficantes sobre a chegada da polícia. Infelizmente, se nada for feito, a tendência é aumentar a violência dos bandidos; imaginem se os bandidos souberem que o cidadão de bem está desarmado? (11. ${ }^{\circ}$ Programa do Não, 11.10.2005)

Outra das representações das mulheres do Não, a segunda mais proeminente, é a mulher-cidadã, que luta pelos seus direitos ou adota uma posição de resistência ou confronto com o Estado, que é apresentado como a instituição que "tira” direitos da população. Esta representação é muitas vezes reforçada com imagens da bandeira brasileira e músicas patrióticas, como o hino brasileiro, bem como excertos de representações de lutas históricas pela liberdade e por direitos civis (como movimentos contra a ditadura, passeatas em defesa de eleições diretas, ${ }^{7}$ hino e bandeira do Brasil, etc.).

Heloísa Chassereaux - Professora de História e Geografia: "Democracia não é só votar. Democracia é o direito de eu ter uma arma, é o direito de eu comer, é o direito de eu trabalhar, é o direito de eu viver, é o direito de eu ter segurança. O Estado me deve tantos direitos, ele está em falta comigo, né? E direitos que eu acho primordiais na minha vida, né? E na vida da população brasileira. Que é o direito à educação, que é o direito à segurança. Como que num momento desse o Estado vem me forçar e vem tirar este direito de eu possuir uma arma? Mesmo que eu não compre esta arma, mas ele não pode tirar este direito. Por isso que eu voto um, que eu voto "Não". (3. 'Programa do Não, 03.10.2005)

Dra. Alda Marco Antonio - Educadora: Se o Brasil quer de fato combater a violência tem que criar escola que ensine de fato e oportunidade de trabalho para todos. (10. ${ }^{\circ}$ Programa do Não, 10.10.2005)

Dr. Luzia Galvão Lopes da Silva - Ex. Promotora do Tribunal do Júri de São Paulo: O que estão fazendo é assegurar a insegurança da população. O cidadão consciente, que pensar realmente no que se pretende com isso, não vai ter a menor dúvida, terá que votar "Não". Não vamos permitir que nos cassem esse direito. Não vamos permitir que nos transformem em cidadão de segunda classe que não tem direito nem a defesa do poder pública nem a autodefesa. (6. ${ }^{\circ}$ Programa do Não, 06.10.2005)

\footnotetext{
7 "Diretas Já" foi um movimento civil de reivindicação de eleições presidenciais diretas no Brasil que teve lugar entre 1983-1984, durante a ditadura. O movimento juntou vários setores da sociedade brasileira, nomeadamente partidos políticos de oposição ao regime ditatorial, líderes sindicais, estudantis e ainda artistas e jornalistas.
} 
No primeiro excerto, a mulher afirma que o desarmamento é apenas mais uma forma de cerceamento de direitos por parte do Estado, razão pela qual vota. No segundo caso, a identidade de "mulher-cidadã" está expressa na afirmação de que o Estado é o responsável pela violência, por omissão ou incompetência, uma vez que não cria os meios necessários para efetivamente a minimizar, designadamente escolas e oportunidade de emprego. Fica implícito que o Estado brasileiro, ao qual se opõe, não "quer de fato combater a violência". Perante esta realidade, justifica-se a opção de luta pela manutenção do direito à defesa com armas de fogo, uma vez que o Estado não a consegue proteger. Já o terceiro testemunho, ao afirmar "não vamos permitir que nos cassem esse direito", marca a sua posição de luta pela manutenção dos seus direitos, que enuncia como o direito de "defesa do poder público" e de "autodefesa".

Estes relatos apresentam o Estado como uma instituição ineficiente no que diz respeito à proteção dos cidadãos, realidade contra a qual as "mulheres-cidadãs" se posicionam. De outro lado, temos a luta declarada pela manutenção dos direitos da população, no caso, o direito à autodefesa, representado pela posse de armas de fogo. $\mathrm{O}$ recurso a imagens de lutas feministas e, mais amplamente, a uma estratégia argumentativa assente nos direitos, que apresenta a posse de arma enquanto direito civil, é bastante semelhante ao usado nos EUA, nomeadamente pela NRA, que emprega a linguagem do feminismo e da luta pelo fim da discriminação racial, ambas associadas a agendas políticas progressistas, para enquadrar a posse de armas, tida como um tema do universo tradicional conservador, na luta pelos direitos civis e políticos (Browder, 2006: 222).

Uma das representações mais recorrentes das mulheres na campanha do Sim é a "mulher-mãe".

Ana Helena Montes, mãe de vítima: Um menino maravilhoso. Um coração do tamanho de um bonde. [...] Perdi meu pai, a dor é muito grande, mas não é um dedinho do pé do que é perder um filho. [...] Eu posso viver mais duzentos anos e eu nunca vou esquecer a imagem do meu filho caído no tapete do elevador. Minha justiça é lutar pelo desarmamento. (1. Programa do Sim, 01.10.2005)

A identificação "mãe de vítima”, usada pela campanha, remete para a construção da mulher-mãe. Para a mulher-mãe, a dor de perder um filho como a pior que existe ("perdi meu pai, a dor é muito grande, mas não é um dedinho do pé do que é perder um filho") e inesquecível ("Eu posso viver mais duzentos anos e eu nunca vou esquecer a imagem do meu filho caído no tapete do elevador"). A frase "minha justiça é lutar pelo desarmamento" 
assinala a luta da mulher por justiça relativamente à morte do filho e em resultado dela. Esta representação é regular nos programas e aparece, por exemplo, no $15{ }^{\circ}$ Programa do Sim, no qual outra mulher-cidadã afirma que se trata de: "um voto certo não só pela nossa vida, mas também por todas as gerações que vão vir", posicionando-se na luta pelo bem comum.

Dentro da representação "mãe de vítima", verifica-se ainda a presença de uma identidade " mulher-vítima":

Valdete da Silva, mãe de vítima: Meu filho é uma criança, meu filho só tem dezassete anos, não viveu ainda. (Imagem: mãe aflita, junto ao filho, que aparece no fundo da imagem, inconsciente, deitado na cama do hospital.) (13. ${ }^{\circ}$ Programa do Sim, 13.10.2005)

Camila M. Lira, vítima: Armas são feitas para destruir vidas, impedir as pernas de andar, correr, dançar. $\left(2 .^{\circ}\right.$ e $8 .{ }^{\circ}$ Programas do Sim)

Ao afirmar que as armas são "feitas para destruir vidas", Camila expõe a sua impotência em resultado da violência que a colocou em uma cadeira de rodas, apresentada pela voz off como "uma prisão que impede o sujeito de viver a vida que levaria se não existissem as armas." (8. Programa do Sim, 08.10.2005).

Maria do Socorro Silva Nóbrega, mãe de vítima: Cada vez que a gente vê na televisão uma mãe chorando, aquela dor é nossa. [...]

Luiza Lopes, Irmã de vítima: Você precisa sentir na pele o que éperder um filho para poder se juntar a nós? Não, a gente tem que se juntar antes que aconteça. [...]

Vera Lúcia Alves, Presidente do Movimento pela Vida: Eu fui muitas vezes a Brasília, conversei muitas vezes com deputados, com deputados que estavam segurando esta lei na mão já tinham dois mandatos.

Valéria Velasco, Presidente do Comité de Vitimas da Violência: Muitas pessoas estão pensando que o Estatuto foi um programa do Governo Federal, se dependesse do Governo Federal, o Estatuto até hoje estaria engavetado ai dentro do Congresso. (5. ${ }^{\circ}$ Programa do Sim, 05.10.2003).

Os dois primeiros relatos expressam a dor dos familiares de vítimas da violência, mas enquanto o primeiro retrata a "mulher-mãe", tomada pelo sofrimento, o segundo apresenta uma mulher que, movida pelo sofrimento, 
atua em prol da comunidade ("Você precisa sentir na pele o que é perder um filho para poder se juntar a nós? Não, a gente tem que se juntar antes que aconteça"). Os últimos testemunhos constituem a "mulher ativista pela paz", que conversou com deputados "várias vezes", disposta a lutar por seus direitos, e cujo ativismo é reforçado pela forma como é apresentada no programa: Presidente do Movimento Pela Vida. Valéria Velasco também é representada enquanto ativista pela paz e líder de um movimento social, que luta contra a inércia do Estado em benefício da comunidade, como se depreende da frase "se dependesse do Governo Federal, o Estatuto até hoje estaria engavetado."

A imagem da "mulher-mãe", uma "boa mãe", é moldada a partir do papel e da responsabilidade tradicionalmente atribuída às mulheres: o cuidado dos outros; enquanto a identidade da "mulher-vítima" é construída por referência ao estereótipo da mulher dependente, seja do marido ou do Estado, que sofre e aparenta ser impotente. A representação da "mulher ativista pela paz" sustém-se através da identificação entre mulheres, solidariedade e não violência como os meios ideais para resolver os problemas, dando prioridade ao bem comum. Esta representação expressa ainda a identidade da mulher feminista, que luta pela obtenção e manutenção de direitos e pelo seu exercício.

Os homens que surgem na campanha pela frente do "Sim" tendem a ser especialistas e profissionais de segurança pública ou outros profissionais - como médicos, juristas - trazendo elementos técnicos e científicos para a discussão ou ainda celebridades que apoiavam a campanha, em vez de populares, vítimas, e ativistas da sociedade civil (Fuks e Paiva, 2006). Deste tipo de homens não são esperados argumentos ou tomadas de posição a favor da proibição com base na sua experiência pessoal de violência, mas sim posições fundamentadas por processos científicos e conhecimento técnico-profissional ou argumentos de natureza ideológica, como ilustram estes excertos:

Gláucio Ary Soares (investigador do Instituto Universitário de Pesquisas do Rio de Janeiro - IUPERJ): Não vemos a tragédia que está acontecendo. Uma tragédia que atinge predominantemente as pessoas mais pobres.

Comandante José Vicente da Silva Jr.: Nos últimos dez anos, só no estado de São Paulo, foram quase 150 mil armas que desapareceram. Armas legais, compradas em lojas, que sumiram das mãos de seu proprietário e foram para nas mãos dos bandidos.

Dalmo de Abreu Dallari (jurista): A arma de fogo não dá vida a ninguém, ela dá a morte. Ela não é instrumento de vida. Ela é um instrumento de ferimento, instrumento de morte e tragédia. (18. ${ }^{\circ}$ Programa do Sim, 18.10.2005) 


\section{A construção sexuada da legítima defesa e da violência armada: "cidadãos de bem", masculinidade maligna e os mitos da vitimação violenta}

A campanha do Sim estruturou-se em torno da defesa do direito à vida e à paz social. Recorrendo a representações sexuadas de vítimas de violência armada, sobretudo mulheres e crianças, apesar de, como referi antes, homens e jovens do sexo masculino constituírem a maioria das vítimas mortais das armas de fogo, esta frente enfatizou os perigos das armas de fogo e a superioridade do direito coletivo à vida face ao direito individual à defesa:

Que direito um homem tem de pegar uma arma durante uma briga e atirar na mulher? Que direito alguém tem de ter uma arma em casa e arriscar a vida de uma criança? Milhares de famílias vivem marcadas pela dor porque alguém achou que tinha o direito de matar. O desejo de possuir uma arma, que é de poucos, não pode ser maior do que o direito à vida, que é de todos nós. (8. Programa do Sim, 08.10.2005)

A difusão deste argumento foi reforçada com o recurso a imagens visuais como as cenas da aprovação do Estatuto do Referendo, da Campanha do Desarmamento e da mobilização pública de mães de vítimas de violência, apresentadas como defensoras da vida e contrárias às armas. A representação das mulheres neste aspeto centra-se nas mães e vítimas da violência e no seu papel enquanto construtoras do Estatuto do Desarmamento e ativistas a favor da proibição, como exemplifica este excerto:

Uma conquista de milhares de famílias que perderam pessoas queridas vítimas de armas de fogo. O Congresso Nacional, atendendo ao apelo e à mobilização popular, aprovou o Estatuto do Desarmamento, uma lei que amplia o direito à vida. (7. ${ }^{\circ}$ Programa do Sim, 07.10.2005)

Já a frente do "Não" concentrou o seu discurso na defesa dos direitos individuais (liberdade, legítima defesa), enfatizando questões morais e princípios de cidadania, ao advogar:

Direito à vida sim, mas desarmar cidadão não é solução. Se votar sim, nunca mais vai poder ter uma arma; se votar não, você poderá ter uma arma, mas não precisa ter. (15. ${ }^{\circ}$ Programa do Não, 15.10.2005)

Mais do que discutir a questão da circulação das armas no Brasil, a campanha alertava a possibilidade de perda de direitos e para a ineficácia da proibição: 
Locutor em off: A proibição não resolve problema nenhum. Só tira um direito do cidadão. Contra a proibição vote não. (19. ${ }^{\circ}$ Programa do Não, 19.10.2005)

Para reforçar esta linha argumentativa, utilizaram-se ainda símbolos e imagens que assinalavam as lutas e conquistas do cidadão brasileiro (comícios, movimentos contra a ditadura, passeatas pelas eleições diretas, hino e bandeira do Brasil, etc.), conquistas essas que, no seu entender, estariam em risco.

No excerto abaixo enuncia-se a lógica de legítima defesa veiculada pela Campanha do Não:

Paulo Pereira da Silva (presidente da Forca Sindical): Sempre fui a favor do desarmamento. Portanto, sempre fui a favor do sim. Depois de ouvir os argumentos pró e contra, hoje estou convencido de que temos que votar não, dia 23. Por quê? Porque o que eles querem é desarmar as pessoas de bem e não os bandidos. Não desarmando os bandidos, depois do dia 23, o bandido terá certeza de que você não tem arma em casa. Ele vai invadir sua casa, estuprar sua mulher, seu filho e você não vai poder fazer nada. Portanto, dia 23 , vote 1 , vote não. (16. ${ }^{\circ}$ Programa do Não, 16.10.2005; ênfase da autora)

Esta narrativa de legítima defesa, expressa na sua maioria por homens, ecoa muitos dos elementos presentes na narrativa sexuada da guerra explicada por Elshtain (1987; 1991): requer masculinidades virtuosas (“cidadãos de bem”) que utilizem a força apenas relutantemente, quando sob ataque ("ele vai invadir sua casa"), e contra "bandidos" sempre que estiverem reunidas razões justas ("ele vai invadir sua casa, estuprar sua mulher, seu filho").

Segundo estes discursos, os "cidadãos de bem" são "bons pais, chefes e maridos", para os quais é importante proteger as suas famílias e propriedades e fazer face aos "bandidos". Neste sentido, a vontade de estarem armados e de terem a possibilidade de se defenderem é apresentada como um sinal de coragem, heroicidade, moralidade e respeito pela lei e ordem, o que os distingue dos "bandidos", que são associados à recusa das a regras e ao prazer pela violência sem sentido. A masculinidade é, assim, central nas duas construções, uma vez que o "cidadão de bem" e o "bandido" são literalmente masculinos.

Além disso, esta narrativa é enunciada e justificada com base na vitimação provável dos homens (violência no espaço público, perpetrada por desconhecidos), não contemplando as características de vitimação mais comuns às mulheres: a violência na esfera doméstica, em resultado da ação de conhecidos. Nas representações da campanha do Não, as mulheres, 
apesar de defenderem o direito a ter armas para fins de proteção e de serem elegíveis a ter armas, na sua maioria, não possuem de facto armas de fogo. O retrato das mulheres é assim próximo da imagem de "almas belas", descrita por Elshtain (1987): são contra violência e guerra, mas anuem e colaboram com a utilização da força tendo em vista proteger a sua inocência e a de outros dependentes.

Segundo um estudo piloto, ${ }^{8}$ realizado em oito das nove Delegacias de Polícia da Mulher no Rio de Janeiro em 2006, com base em 615 questionários preenchidos por mulheres denunciantes de violência, $60.3 \%$ das denunciantes tinha sido agredida pelo companheiro ou ex-companheiro. Entre as denunciantes que sabiam que o agressor tinha uma arma de fogo, $68,5 \%$ responderam que já tinham sido ameaçadas de alguma forma com a arma. $73 \%$ referiram que a presença da arma as impedia de reagir física ou verbalmente à violência, sendo que $68 \%$ afirmaram que gostariam de pôr um fim na relação com o agressor, mas que não o faziam porque temiam ser agredidas com a arma. $65 \%$ do total de denunciantes responderam ainda que se sentiriam mais seguras se a venda de armas fosse proibida; e 70\% declararam-se a favor da proibição da venda de armas e munições. Relevante é também a percentagem de denunciantes que afirmou não saber se o parceiro íntimo tinha uma arma em casa $(24,6 \%)$. Não saber significa ter que lidar com essa dúvida, não esquecendo que para manter e perpetuar uma relação de dominação e de poder, a arma não tem necessariamente que ser usada, ou mesmo vista (Moura, 2007).

Bárbara Soares sublinha alguns destes pontos da narrativa sexuada da legítima defesa, enfatizando a artificialidade da separação entre "cidadãos de bem" e "bandidos" no que diz respeito à violência cometida contra mulheres. Nota que entre os mais denunciados pela violência que atinge as mulheres não estão nem "os traficantes e assaltantes aquartelados nas favelas, nem os milhares de cidadãos honestos que vivem nessas comunidades. São também e sobretudo os que habitam o asfalto.” Enfatiza ainda o papel das armas de fogo em situações de violência doméstica: "Obviamente, não é necessário ter armas para praticar violência doméstica. Mas a presença das armas é um dos fatores que impede as vítimas de reagir, de denunciar e até de escapar de seus agressores" (Soares, 2005).

A raça e a classe também estão implicadas neste discurso sobre legítima defesa e, em termos mais específicos, na forma como se imaginam e articulam

\footnotetext{
${ }^{8}$ Estudo realizado pelo Núcleo de Estudos para a Paz (CES/UC) e o Centro de Estudos sobre Segurança e Cidadania (CESeC, Universidade Cândido Mendes, Brasil), no âmbito do projeto de investigação "Mulheres e meninas em contextos de violência armada. O estudo de caso sobre o Rio de Janeiro.”
} 
as fontes de ameaça à segurança pública e os alvos da vulnerabilidade. A frente do Não identifica a ameaça principal à segurança pública - contra a qual é imperativo exercer o direito de legítima defesa - com a juventude pobre, negra, oriunda de estratos sociais marginalizados, e associada com o tráfico de drogas:

Pivô: O Programa do Fantástico mostrou recentemente o efeito da mistura entre juventude, o mundo do tráfico e as armas. São jovens consumindo drogas e carregando armas ilegais [imagens de favelas, rapazes fortemente armados e assaltos de carro]. Eles ficam em pontos estratégicos do morro para alertar os traficantes sobre a chegada da polícia. Infelizmente, se nada for feito, a tendência é aumentar a violência dos bandidos; imaginem se os bandidos souberem que o cidadão de bem está desarmado? (11. ${ }^{\circ}$ Programa do Não, 11.10.2005)

Esta narrativa sobre vítimas e transgressores prováveis revela não só a resistência da expressão "homem negro criminoso" (Russell, 2009: 3), como também o perfil racial e de classe dos proponentes da legítima defesa da campanha do Não. De facto, e apesar de, como referi antes, a maioria das vítimas diretas da violência armada no Brasil serem jovens do sexo masculino, negros, e pobres, a narrativa da legítima defesa é veiculada, na sua maioria, por homens, oriundos da classe média/média-alta brasileira. A necessidade de armas de fogo como instrumentos de defesa é justificada por estes segundo a sua ótica (imaginada) de vitimação provável: crimes violentos contra a propriedade e, em menor grau, crimes contra pessoas, cometidos por grupos criminosos organizados, em especial os associados ao tráfico de drogas, que têm lugar nas áreas urbanas e suburbanas de classe média e média-alta.

Todavia, este padrão de vitimação não é sustentado pelas características mais comuns da violência armada a nível nacional e que colocam os homens negros, pobres e jovens, residentes em áreas urbanas degradadas, em posição de maior vulnerabilidade (Instituto Sangari e Ministério da Justiça, 2012). Segundo o estudo do Instituto Sangari, as taxas de homicídio no Brasil têm cor: no ano de 2010 foram em média duas vezes mais elevadas para vítimas de cor negra do que branca. Além desta diferença estatística no ano referido, as taxas também têm vindo a diminuir em relação a brancos nos últimos dez anos, enquanto para os negros têm aumentado: em termos médios, em 2002 o estudo aponta uma taxa de 20,6 assassinatos de brancos por 100000 habitantes, e de 30 para negros; em 2010, esse índice cai para 15 homicídios de vítimas brancas, mas sobe para 35,9 entre as negras (ibidem: 8-10). Desta forma, os discursos sobre legítima defesa ignoram 
a discussão de dinâmicas de desigualdade e privilégio social mais amplas, centrando-se, ao invés disso, na necessidade de defesa daqueles que têm menos probabilidade de serem vítimas de violência armada.

No que se refere à frente do Sim, as fontes de violência e insegurança no Brasil iam além da criminalidade organizada e do tráfico. Centrando-se na violência armada prevenível através da proibição e desarmamento civil, ou seja, a violência interpessoal, cometida por motivos como raiva, revolta, tensão, álcool e ciúme e também nos acidentes domésticos e suicídios, que, segundo um estudo da Secretaria de Segurança Pública de São Paulo, corresponderiam a 95\% das mortes causadas por armas de fogo (05.10.2005), o Sim defende que não faz sentido distinguir entre "cidadãos de bem" e "bandidos":

Angélica: O Brasil é marcado pela desigualdade social e a violência urbana. Mudam governos e não investem em segurança, [temos] desemprego e exclusão social, policiais mal remunerados e trabalhando em péssimas condições. Os problemas são muitos e, para piorar, 15 milhões de armas nas mãos de civis. O resultado disso tudo: o triste título de campeão mundial em mortes por armas de fogo. (9. ${ }^{\circ} / 10$. $^{\circ}$ Programas do Sim)

A campanha do Não destacou o problema do contrabando de armas, o crescimento da criminalidade e questões sociais, como desemprego e acesso à educação, visando desconstruir alguns dos argumentos da frente do Sim, nomeadamente o possível abastecimento dos bandidos através do roubo e desvio de armas (supõe-se que legais) aos cidadãos comuns, já que a maioria dos homicídios decorreria de acidentes domésticos, crimes passionais e conflitos interpessoais. Para a frente do Não, os "cidadãos de bem" não podiam ser responsabilizados pela violência uma vez que os "bandidos", dotados de armas ilegais, constituíam os principais agentes da violência e os responsáveis pelas mortes por arma de fogo no país, enquanto os demais homicídios seriam "exceções" (9. Programa do Não). Esta construção social da violência armada privilegia a expressão pública deste tipo de violência, que afeta maioritariamente os homens, sem, contudo, os colocar uma vez sequer na posição de vítima e usando personagens femininas e crianças como exemplos de vítimas desta violência. O resultado desta construção masculinizada da violência armada é a marginalização das experiências violentas das mulheres, nomeadamente o papel das armas de fogo em contextos de violência doméstica.

Reconhecendo os limites do Estado enquanto garante de segurança ("Mudam os governos e não investem em segurança"), emprego e inclusão 
social, o Sim defende a manutenção do monopólio da força do Estado ("Para piorar, 15 milhões de armas nas mãos de civis"), abdicando de parte de sua liberdade em prol da paz e coletiva e afirma que "Precisamos fazer a nossa parte e exigir que o governo faça a dele” (Programa do Sim, 05.10.2005). Neste sentido, a proibição seria um passo para garantir a segurança, o que teria de ser completado com outros mecanismos de proteção e resposta à criminalidade e violência.

Já a campanha do Não defendia que os problemas sociais que dão origem à grande parte da criminalidade não seriam afetados pela proibição do comércio de armas. Para o Não, a resposta do Estado, perante a sua incapacidade de proteger os cidadãos, deveria ser delegar mais liberdade aos indivíduos sobre a provisão de segurança, garantindo o direito à legítima defesa aos "cidadãos de bem". Esta proposta sugere uma versão individualizada e masculinizada de segurança, assente na autossuficiência e no hiperindividualismo, que mantém vários elementos em comum com o ideal de utilizador de armas avançado pela NRA nos EUA (O'Neill, 2007). Segundo esta proposta, as armas de fogo são símbolos máximos de responsabilidade pessoal e autossuficiência, ocultando, contudo, relações de interdependência sobre as quais se constroem sociedades.

\section{Conclusão}

É evidente a importância do género na construção dos argumentários de ambas as frentes e consequentemente nas perceções sobre violência armada e segurança pública. Ambas recorreram de forma repetida não só a personagens femininas e masculinas para explicar os argumentos e o que estava em causa no Referendo - para o Sim o "direito à vida" e para o Não "o direito a direitos e a legítima defesa" -, como frequentemente também a narrativas sexuadas da violência armada e insegurança no país.

As duas frentes usam narrativas híbridas, mas igualmente sexuadas, sobre mulheres e homens para justificar e mobilizar as suas posições, procurando apelar a um maior número de pessoas possível (homens e mulheres) num contexto mais amplo de transformação de atitudes acerca dos papéis e expetativas das mulheres. Este hibridismo mistura elementos discursivos do maternalismo militante (mulheres enquanto cuidadoras) e da igualdade (mulheres enquanto sujeitos de direitos), na tentativa de mobilizar grupos heterogéneos de votantes. Tratam-se ainda assim de representações sexuadas com implicações sobre os significados sociais de criminalidade, vitimação e segurança.

De facto, o destaque atribuído às mulheres na campanha e a presença de múltiplos retratos de mulheres nos discursos de cada frente parece 
indicar que a subordinação de género foi desconstruída na e pela campanha. Contudo, estes discursos assentaram na diferenciação de papéis entre homens e mulheres ("mulher honesta e desprotegida", "mulher cidadã", que quer o direito de se defender, mas que, na esmagadora maioria das vezes, não tem arma de fogo versus "homem de bem", cidadão armado, a quem se atribui o direito e o exercício da legítima defesa, do lado do Não; "mulher-mãe-vítima" e "mulher ativista pela paz", geralmente em resultado de motivos pessoais versus homem especialista ou profissional, que se posiciona a favor da proibição por motivos profissionais e ideológicos) de forma a mobilizar aceitação e recusa da proibição que se sustêm nas mesmas diferenças e as reconstituem. Estas representações das mulheres nas duas frentes definem o que as mulheres são e devem ser: honestas, boas e objeto de proteção, mães, vítimas, cidadãs pacíficas, movidas sobretudo por razões pessoais, excluindo outros retratos possíveis e reais, como o das mulheres utilizadoras de armas por motivos de defesa (só é representado um caso) e recreativas (caça e desporto). Simultaneamente, as campanhas definem o que os homens são e devem ser: agentes de proteção e transgressão, "cidadãos de bem" (com armas), e especialistas de segurança pública, omitindo o facto de que constituem a larga maioria das vítimas mortais e não mortais deste tipo de violência. Em grande medida, portanto, estas representações tendem a manter intactos os tipos ideais de feminilidade bem como de masculinidade.

A prevalência de representações conservadoras de género repercute-se nas perceções de violência e insegurança que se veiculam nas campanhas, com destaque para construções sexuadas de violência armada, legítima defesa e segurança pública da Frente do Não, que têm como referência sobretudo as fontes, locais e agentes de insegurança provável de alguns homens (violência na esfera pública, resultado da ação de desconhecidos, como "tráfico" e os "bandidos", e em especial, da utilização de armas ilegais). O direito à legítima defesa, veiculado pela campanha do Não, é expressão do padrão de vitimação provável masculina, não contemplando as características de vitimação mais comuns às mulheres: a violência na esfera doméstica, e onde a arma de defesa pessoal pode ser instrumento de ataque e intimidação e vetor de acidentes. Os proponentes da legítima defesa, em larga maioria homens, representam ainda, em traços gerais, a classe média/ /média-alta brasileira, dando atenção, aos homens e às mulheres brancos, de áreas urbanas e suburbanas enquanto vítimas de violência armada. Esta representação da vitimação é, contudo, desproporcional ao que revelam as estatísticas sobre mortalidade violenta no Brasil, que colocam os homens negros, pobres e jovens, residentes em áreas urbanas degradadas, em posição de maior vulnerabilidade face à violência armada. 
Perante este cenário, para a frente do Não, a resposta do Estado, perante a sua incapacidade de proteger os cidadãos, deve ser delegar mais liberdade aos indivíduos sobre a provisão de segurança, garantindo o direito à legítima defesa aos "cidadãos de bem"; enquanto a frente do Sim defende o contrato social firmado entre cidadão e Estado, segundo o qual os indivíduos delegam no Estado o monopólio da força, abrindo mão de parte da sua liberdade em prol da paz e da segurança coletivas, e o reforço dos mecanismos de proteção e resposta à criminalidade e violência, nomeadamente a reforma da polícia.

\section{Referências bibliográficas}

Berdal, Mats (1996), "Disarmament and Demobilisations After Civil Wars", Adelphi Paper, 303. Oxford: IISS e Oxford University Press.

Browder, Laura (2006), Her Best Shot. Women and Guns in America. Chapel Hill: University of North Carolina Press.

Burgieres, Mary (1990), "Feminist Approaches to Peace: Another Step for Peace Studies", Millenium: Journal of International Studies, 19, 1-18.

Butler, Joanne (1994), "Contingent Foundations: Feminism and the Question of Post-Modernism”, in S. Seidman (org.), The Postmodern Turn: New Perspectives on Social Theory. Cambridge: Cambridge University Press, 153-170.

Cohn, Carol; Ruddick, Sara (2004), "A Feminist Ethical Perspective on Weapons of Mass Destruction", in Sohail H. Hashmi e Steven P. Lee (orgs.), Ethics and Weapons of Mass Destruction. Religious and Secular Perspectives. Cambridge: Cambridge University Press, 405-435.

Connell, R. W (1995), Masculinities. Cambridge, UK: Polity.

Connell, R. W.; Messerschmidt, J. W. (2005), "Hegemonic Masculinity: Rethinking the Concept", Gender \& Society, 19, 829-859.

Cony, Carlos Heitor (2005), "A solução radical”, Folha de S. Paulo, de 26/10/2005.

Cunha, Christina Vital da (2006), "'Referendo das armas': propaganda televisiva e percepções da população". Comunicações do ISER, n. ${ }^{\circ} 62$ (Referendo do Sim ao Não: Uma Experiência da Democracia Brasileira), 57-70.

Deutsch, Francine M. (2007), "Undoing Gender", Gender E Society, 21 (1), 106-127.

Dietz, Mary G. (1985), "Citizenship with a Feminist Face: The Problem with Maternal Thinking”, Political Theory, 13, 19-37.

Dreyfus, Pablo; Nascimento, Marcelo S. (2005), "Posse de armas de fogo no Brasil: mapeamento das armas e dos seus proprietários", in Rúben C. Fernandes (org.), Brasil: as armas e as vítimas. Rio de Janeiro: 7 Letras, 126-196.

Elshtain, Jean B. (1987), Women and War. New York: Basic Books. 
Elshtain, Jean B. (1991), “Sovereignty, Identity, Sacrifice”, Millennium: Journal of International Studies, 20(3), 395-406.

Enloe, Cynthia (1983), Does Khaki Become You? The Militarization of Women's Lives. London: Pluto Press.

Enloe, Cynthia (2000), Maneuvers: The International Politics of Militarizing Women's Lives. Berkeley/Los Angeles: University of California Press.

Farr, Vanessa; Myrttinen, Henri; Schnabel, Albrecht (2009), Sexed Pistols: The Gendered Impacts of Small Arms and Light Weapons. New York: United Nations University Press.

Flood, Michael (1999), "Victim Feminism and Power Feminism”. Comunicação no âmbito do seminário "Introducing Women's Studies: The Public Life of Feminism”, Women's Studies, Universidade Nacional Australiana, 13 de abril.

Fuks, Mario; Paiva, Daniela (2006), "Persuasão e deliberação sobre políticas públicas. A propaganda política no 'Referendo das Armas'”, in Inácio Magna, Raquel Novais e F. Anastasia (orgs.), Democracia e referendo no Brasil. Belo Horizonte: Editora UFMG, 206-248.

Geneva Declaration (2011), The Global Burden of Armed Violence. Geneva: Geneva Declaration Secretariat.

Gibson, James (1994), Warrior Dreams: Paramilitary Culture in Post-Vietnam America. New York: Hill and Wang.

Gilligan, Carol (1982), In a Different Voice: Psychological Theory and Women's Development. New York: Harvard University Press.

GunPolicy.org (2011), "Small Arms in Brazil: Facts, Figures and Firearms law". Consultado a 12.08.2012, em http://www.gunpolicy.org/firearms/region/brazil.

Hollander, Jocelyn A. (2004), "I Can Take Care of Myself: The Impact of Self-Defense Training on Women's Lives”, Violence Against Women, 10, 205-235.

Instituto Sangari e Ministério da Justiça (2011), Mapa da violência 2011. Os jovens do Brasil. Brasília: Instituto Sangari e Ministério da Justiça.

Instituto Sangari e Ministério da Justiça (2012), Mapa da violência 2012. A cor dos homicídios no Brasil. Brasília: Instituto Sangari e Ministério da Justiça.

Jones, Ann (1994), "Living with Guns, Playing with Fire”, Ms., maio/junho, 43-58.

Kellner, Douglas (2008), Guns and Guys Amok. Domestic Terrorism and the School Shootings from the Oklahoma City Bombing to the Virginia Tech Massacre. Boulder/ Londres: Paradigm Publishers.

Kimmel, Michael (1996), Manhood in America: A Cultural History. New York: Free Press. Kimmel, Michael (2010), "Masculinity as Homophobia: Fear, Shame, and Silence in the Construction of Gender Identity.”, in Michael S. Kimmel e Abby L. Ferber (orgs.), Privilege. Boulder: Westview, 51-74.

Miller, M.; Azrael, D.; Hemenway, D. (2000), "Community Firearms and Community Fear", Epidemiology, 11, 709-714. 
Moura, Tatiana (2007), Rostos invisiveis da violência armada. Rio de Janeiro: 7 Letras.

Moura, Tatiana; Santos, Rita; Pureza, José M. (2013), Portugal: violência e armas de fogo. Coimbra: Editora Almedina.

Muggah, Robert (2006), "Emerging from the Shadow of War: A Critical Perspective on DDR and Weapons Reduction in the Post-Conflict Period", Contemporary Security Policy, 27(1), 190-205.

O’Neill, Kevin Lewis (2007), “Armed Citizens and the Stories they Tell: The National Rifle Association's Achievement of Terror and Masculinity", Men and Masculinities, 9, 457-75.

Peach, Lucinda J. (2004), "A Pragmatist Feminist Approach to the Ethics of Weapons of Mass Destruction”, in Sohail H. Hashmi e Steven P. Lee (orgs.), Ethics and Weapons of Mass Destruction. Religious and Secular Perspectives. Cambridge: Cambridge University Press, 436-450.

Pettman, Jan Jindy (1996), Worlding Women: A Feminist International Politics. London: Routledge.

Reardon, Betty (1985), Sexism and the War System. New York: Teachers College Press.

Russell, Katherine (2009), The Color of Crime. New York: New York University Press.

Ruddick, Sara (1982), "Maternal Thinking”, in Sara Ruddick, Maternal Thinking - Towards a Politics of Peace. Boston: Beacon Press, 13-27.

Shepherd, Laura J. (2008), Gender, Violence and Security. Discourse as Practice. London/ New York: Zed Books.

Sjoberg, Laura; Gentry, Caron E. (2007), Mothers, Monsters and Whores. Women's Violence in Global Politics. London: Zed Books.

Small Arms Survey (2005), Weapons at War. Oxford: Oxford University Press.

Soares, Barbara (2005), "Legítima defesa de quem?", Jornal do Brasil, 25 de outubro.

SEESAC - South Eastern Europe Clearinghouse for the Control of Small Arms and Light Weapons (2003), Regional Micro-disarmament Standards/Guidelines. Ammunition and Explosives Stockpile Management. Consultado a 08.08.2012, em http://www.smallarmssurvey.org/files/portal/spotlight/ammunition/ammun_pdf/2006_SEESAC.pdf.

Stange, Mary Zeiss; Oyster, Carol K. (2000), Gun Women: Firearms and Feminism in Contemporary America. New York: New York University Press.

Stiehm, Judith (1982), "The Protected, the Protector, the Defender", Women's Studies International Forum, 5, 367-376.

Stretesky, P. B.; Pogrebin, M. R. (2007), "Gang-related Gun Violence: Socialization, Identity, and Self”, Journal of Contemporary Ethnography, 36, 85-114.

Stroud, Angela (2012), "Good Guys with Guns: Hegemonic Masculinity and Concealed Handguns”, Gender and Society, 26(2), 216-238. 
Tickner, Ann (1992), Gender in International Relations - Feminist Perspectives on Acbieving Global Security. New York: Columbia University Press.

Westwood, Sallie; Radcliffe, Sarah (1993), "Gender, Racism and the Politics of Identities in Latin America”, in Sallie Westwood e Sarah Radcliffe (orgs.), Viva. Women and Popular Protest in Latin America. London: Routledge, 1-29.

Wolf, Naomi (1993), Fire with Fire. The New Female Power and How to Use It. New York: Ballantine Books. 